\title{
The in vivo growth and development of micropropagated Elatior begonias (Begonia $\times$ hiemalis). II. Study on the effect of chlormequat and ancymidol.
}

\author{
PÄIVI ROIVAINEN \\ Department of horticulture, University of Helsinki, \\ SF-00710 Helsinki, Finland
}

\begin{abstract}
Micropropagation is an efficient means of producing pathogen-free Elatior begonias. However, the growth of the micropropagated plants can be too luxuriant, flowering is often delayed and the root collars remain thin, all unwanted growth habits in commercial production.

To study the effect of growth retardants, an experiment was arranged in spring 1987, in which chlormequat and ancymidol were used on the micropropagated Elatior begonia 'Afrodite Limelight'. Both growth retardants were sprayed at three concentrations: 500,1000 or 1500 ppm of chlormequat and $37.5,50.0$ or $62.5 \mathrm{ppm}$ of ancymidol. Spraying was performed once, twice or three times. Plants not receiving any growth retardants were used as controls.

The time taken to reach anthesis and the sale stage differed significantly between treated and untreated plants only in the begonias sprayed twice with $1000 \mathrm{ppm}$ chlormequat, which reached anthesis one week later than the controls. Both of the growth regulators reduced the growth in height, and ancymidol also reduced the growth in width. The flower stalks were significantly shorter in plants treated with ancymidol or two or three times with chlormequat than in the controls. No differences were observed in the number of branches, flowers or flower buds, or in the diameter of the root collar.

The greatest proportions of saleable plants were obtained by spraying once with 500 or $1000 \mathrm{ppm}$ chlormequat or leaving the plants untreated. The concentrations of ancymidol were too high, since the plants treated with this growth regulator were extremely compact and unsaleable.
\end{abstract}

Index words: Begonia $\times$ hiemalis, micropropagation, growth regulator, chlormequat, ancymidol.

\section{Introduction}

Elatior begonias (Begonia $\times$ hiemalis) have become very popular as flowering pot plants. Traditionally, they are propagated by leaf or stem cuttings, depending on the cultivar. With the general development of methods of tissue culture, micropropagation of Elatior begonias has also become possible and has proved to be an efficient means of producing a large number of healthy plants in a short time. In this way it is possible to control the spread of 
one of the most serious diseases of Elatior begonia, bacterial leaf spot and blight caused by Xanthomonas begoniae. As no efficient chemical control of this disease is available at the moment, it is easily spread with traditionally propagated cuttings.

In spite of the superior healthiness of the plants, commercial producers have not been completely satisfied with the micropropagated Elatior begonias. When grown in the same way as traditionally propagated plants, they are said to show luxuriant and elongated growth together with delayed flowering. Thinness of the root collar has also been reported, which poses a special problem in vigorously growing cultivars with a heavy crown.

The aim of this study was to investigate the effect of growth retardants on the growth and development of micropropagated Elatior begonias. Growth retardants such as daminotzide (succinic acid-2,2-dimethylhydrazide), chlormequat ((2-chloroethyl) trimethylammonium chloride) and ancymidol ( $\alpha$-cyclopropyl$\alpha$-(4-methoxyphenyl)-5-pyrimidinemethanol) are widely used in commercial pot plant production, to make the plants more compact in shape and to improve quality. In Elatior begonias daminotzide has failed to retard growth (Hilding 1975, Krauskopf and Nelson 1976, WILL 1977), whereas chlormequat and ancymidol have proved efficient growth retardants (Sandved 1972, 1984, Hilding 1975, KrausKOPF and Nelson 1976, WILl 1977, WIKESJÖ 1978, SCHENK and BRUNDERT 1980, AdriANSEN 1983, Hentig and KNÖSEl 1984).

\section{Materials and methods}

The research was done with the commercially micropropagated Elatior begonia 'Afrodite Limelight'. At the beginning of the experiment, the plants were at the growth stage at which the commercial producers receive them, 5-10 cm high. They were potted on 3. 3. 1987 in 12-cm plastic pots, using a substrate with three parts of B2-peat (Sphagnum peat with $0.95 \%$ of $10-11.3-16$-fertilizer and $6.2 \%$ of dolomite lime by weight, medium sieving grade) and one part of perlite. After this the plants were transferred to a greenhouse.

The plants were lighted with incandescent lamps at $04.00-08.00$ hours and at $16.00-$ 20.00 hours for 3 weeks, to maintain the vegetative condition. The plants were then given a short-day treatment of 3 weeks, during which the light-dark cycle was 8 hours light and 16 hours dark. After the short-day treatment, the plants were grown in natural daylength.

Two growth retardants were used, chlormequat (CCC $75 \%$ ) and ancymidol (Reducymol), both as sprays. One half of the plants was sprayed with chlormequat and the other half with ancymidol. Both halves were divided into three different solution groups:

group 1. $500 \mathrm{ppm}$ chlormequat or $37.5 \mathrm{ppm}$ ancymidol

group 2. $1000 \mathrm{ppm}$ chlormequat or $50.0 \mathrm{ppm}$ ancymidol

group 3. $1500 \mathrm{ppm}$ chlormequat or $62.5 \mathrm{ppm}$ ancymidol

Each of these solution groups was divided into three groups according to the number of times that they were sprayed:

group 1. Sprayed once, just before the shortday treatment

group 2. As for group 1, but sprayed once more after 2 weeks

group 3. As for group 2, but sprayed once more after 2 weeks

A group of plants receiving no growth retardants were used as controls. The sprays were applied to the point of run-off. The night temperatures were intended to vary with the growing stage, as follows: vegetative period $+17^{\circ} \mathrm{C}$, short-day treatment $+20^{\circ} \mathrm{C}$ and time to flowering $+15^{\circ} \mathrm{C}$. In practice, however, these temperatures were difficult to keep and the night temperature range observed was $+14-+17^{\circ} \mathrm{C}$ (veg.), $+16-+20^{\circ} \mathrm{C}$ (shortday) and $+16-+18^{\circ} \mathrm{C}$ (flow.). Fertilizing was begun 3 weeks after potting. A fertilizer 
with $14 \% \mathrm{~N}, 5 \% \mathrm{P}, 21 \% \mathrm{~K}$ plus micronutrients was used. Nutrients were applied at every watering at the rate of $112 \mathrm{ppm} \mathrm{N}, 38$ ppm $\mathrm{P}$ and 168 ppm $\mathrm{K}$.

A completely randomized design was used with six replications. Height was measured from the pot rim to the highest peak of the plant. Width was determined as the average of two measurements at right angles to each other. The beginning of anthesis was determined as the date when the first open flower was observed and the sale stage was determined as the date when six flowers were open. The number of branches was counted and the diameter of the root collar was measured on the top of the growing substrate. The diameter measurement of the root collar was taken from the first-flowering branch. The length of the flower stalk was measured from the first opened flower.

When a plant had reached the sale stage, the experiment was terminated for its part and the height, width, number of branches, flowers and flower buds, length of the flower stalk, diameter of the root collar and saleability were observed. As there are no official requirements concerning the saleability of Elatior begonias, a subjective judgement was used and the results in Figure 2 are thus merely indicative. The whole experiment was terminated on 26. 5. 1987, i.e. 12 weeks after potting and 9 weeks after the beginning of the short-day treatment.

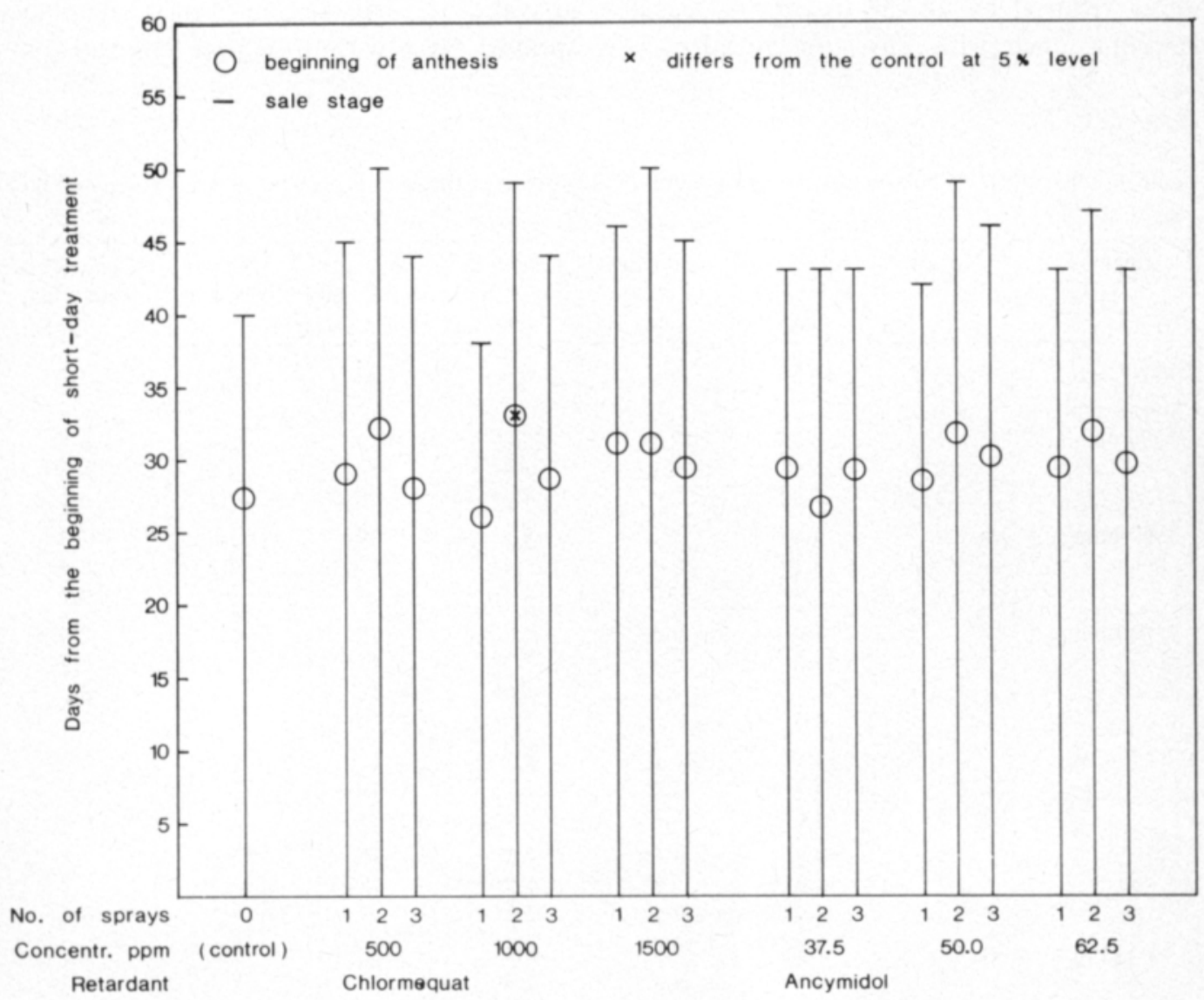

Fig. 1. The effect of chlormequat and ancymidol sprays on the time taken to reach anthesis and the sale stage in Elatior begonia 'Afrodite Limelight'. 


\section{Results}

The time taken to reach anthesis was significantly longer (1 week) only in the plants treated twice with 1000 ppm chlormequat, compared with the untreated plants. The time taken to reach the sale stage was not significantly affected by either of the retardants. However, the retardants seemed to delay flowering to some extent. Plants treated twice with any concentration were in most cases the last to reach anthesis and the sale stage (Figure 1).

The height of the plants was reduced by every growth regulator treatment. Spraying with ancymidol caused excessive growth retardation, especially at the concentration of 62.5 ppm. The increase in width was significantly reduced by ancymidol but not by chlormequat. The length of the flower stalk was markedly reduced by all the treatments except spraying once with any concentration of chlormequat. The flower stalks of plants treated with ancymidol were extremely short. No differences were observed in the number of branches, flowers or flower buds, or in the diameter of the root collar (Table 1).

The greatest proportions of saleable plants were obtained by spraying once with 500 or $1000 \mathrm{ppm}$ chlormequat or leaving the plants untreated. None of the plants treated with ancymidol or twice with $1500 \mathrm{ppm}$ chlormequat were saleable (Figure 2). No leaf damage was observed with any treatment. The leaves of the plants treated with ancymidol were darker green than those of the plants treated with chlormequat or the control plants.

\section{Discussion}

Chlormequat and ancymidol did not significantly delay the beginning of flowering or arrival at the sale stage, except in the plants sprayed twice with 1000 ppm chlormequat.

Table 1. The effect of chlormequat and ancymidol on the growth of the Elatior begonia cultivar 'Afrodite Limelight'.

\begin{tabular}{|c|c|c|c|c|c|c|c|}
\hline Treatment & $\begin{array}{l}\text { No. of } \\
\text { sprays }\end{array}$ & $\begin{array}{c}\text { Increase } \\
\text { in height } \\
(\mathrm{cm})\end{array}$ & $\begin{array}{l}\text { Increase } \\
\text { in width } \\
(\mathrm{cm})\end{array}$ & $\begin{array}{l}\text { Length of } \\
\text { flower stalk } \\
(\mathrm{cm})\end{array}$ & $\begin{array}{c}\text { No. of } \\
\text { flowers and } \\
\text { flower buds }\end{array}$ & $\begin{array}{c}\text { No. of } \\
\text { branches }\end{array}$ & $\begin{array}{c}\text { Diameter of } \\
\text { root collar } \\
(\mathrm{mm})\end{array}$ \\
\hline Control & - & 11.6 & 9.0 & 6.4 & 20 & 2.3 & 7.5 \\
\hline $\begin{array}{c}\text { Chlormequat } \\
500 \text { ppm } \\
" \\
"\end{array}$ & $\begin{array}{l}1 \\
2 \\
3\end{array}$ & $\begin{array}{l}8.8^{*} \\
6.5^{*} \\
7.6^{*}\end{array}$ & $\begin{array}{l}8.1 \\
8.8 \\
7.4\end{array}$ & $\begin{array}{l}5.0 \\
3.8^{*} \\
4.6^{*}\end{array}$ & $\begin{array}{l}19 \\
20 \\
19\end{array}$ & $\begin{array}{l}2.3 \\
4.2 \\
2.4\end{array}$ & $\begin{array}{l}6.7 \\
6.2 \\
6.9\end{array}$ \\
\hline $\begin{array}{c}1000 \mathrm{ppm} \\
\text { " } \\
n\end{array}$ & $\begin{array}{l}1 \\
2 \\
3\end{array}$ & $\begin{array}{l}8.4^{*} \\
6.2^{*} \\
7.7^{*}\end{array}$ & $\begin{array}{l}7.1 \\
8.1 \\
7.0\end{array}$ & $\begin{array}{l}5.0 \\
3.4^{*} \\
4.3^{*}\end{array}$ & $\begin{array}{l}19 \\
17 \\
20\end{array}$ & $\begin{array}{l}1.6 \\
3.2 \\
2.0\end{array}$ & $\begin{array}{l}7.0 \\
6.8 \\
7.1\end{array}$ \\
\hline $\begin{array}{c}1500 \mathrm{ppm} \\
\text { " } \\
n\end{array}$ & $\begin{array}{l}1 \\
2 \\
3\end{array}$ & $\begin{array}{l}7.7^{*} \\
7.0^{*} \\
6.7^{*}\end{array}$ & $\begin{array}{l}7.4 \\
6.9 \\
7.2\end{array}$ & $\begin{array}{l}4.6 \\
3.9^{*} \\
4.0^{*}\end{array}$ & $\begin{array}{l}19 \\
14 \\
19\end{array}$ & $\begin{array}{l}2.5 \\
2.5 \\
2.4\end{array}$ & $\begin{array}{l}7.0 \\
7.0 \\
6.8\end{array}$ \\
\hline $\begin{array}{c}\text { Ancymidol } \\
37.5 \mathrm{ppm} \\
n \\
"\end{array}$ & $\begin{array}{l}1 \\
2 \\
3\end{array}$ & $\begin{array}{l}4.5^{*} \\
4.8^{*} \\
4.6^{*}\end{array}$ & $\begin{array}{l}6.7 \\
5.2^{*} \\
4.8^{*}\end{array}$ & $\begin{array}{l}2.5^{*} \\
3.1^{*} \\
2.6^{*}\end{array}$ & $\begin{array}{l}21 \\
19 \\
23\end{array}$ & $\begin{array}{l}3.3 \\
2.7 \\
2.3\end{array}$ & $\begin{array}{l}6.7 \\
7.0 \\
6.6\end{array}$ \\
\hline $\begin{array}{c}50.0 \mathrm{ppm} \\
\quad " \\
"\end{array}$ & $\begin{array}{l}1 \\
2 \\
3\end{array}$ & $\begin{array}{l}4.8^{*} \\
4.0^{*} \\
3.4^{*}\end{array}$ & $\begin{array}{l}4.5^{*} \\
5.7^{*} \\
4.4^{*}\end{array}$ & $\begin{array}{l}2.5^{*} \\
1.9^{*} \\
2.2^{*}\end{array}$ & $\begin{array}{l}15 \\
18 \\
19\end{array}$ & $\begin{array}{l}2.8 \\
3.7 \\
3.2\end{array}$ & $\begin{array}{l}7.2 \\
6.3 \\
6.4\end{array}$ \\
\hline $\begin{array}{c}62.5 \mathrm{ppm} \\
" \\
"\end{array}$ & $\begin{array}{l}1 \\
2 \\
3\end{array}$ & $\begin{array}{l}2.5^{*} \\
2.8^{*} \\
3.8^{*}\end{array}$ & $\begin{array}{l}5.3^{*} \\
4.8^{*} \\
5.3^{*}\end{array}$ & $\begin{array}{l}2.3^{*} \\
1.9^{*} \\
2.6^{*}\end{array}$ & $\begin{array}{l}19 \\
20 \\
24\end{array}$ & $\begin{array}{l}2.7 \\
3.3 \\
3.0\end{array}$ & $\begin{array}{l}7.0 \\
6.2 \\
6.5\end{array}$ \\
\hline
\end{tabular}

* Means in the same column differ significantly from the control in the MSD test, $5 \%$ level. 
HiLDING (1975) studied the effect spraying with $0.04-0.1 \%$ chlormequat $(400-1000$ ppm) and reports that no differences were observed in the beginning of anthesis between treated and untreated plants in summer. Late in autumn, treatment with chlormequat caused slight retardation of flowering.

In this experiment strong reduction of height was obtained by using ancymidol. Even the lowest concentration, $37.5 \mathrm{ppm}$, sprayed only once, caused the plants to become dwarfed. KrausKopf and Nelson (1976), who investigated the effect of spraying with 16.5 and $33 \mathrm{ppm}$ ancymidol on the cultivar 'Schwabenland Red', report that these concentrations were ineffective both in autumn (October) and in spring (March). It is likely that differences exist between the cultivars of Elatior begonia in the sensitivity to growth regulators. This conclusion is supported by the report of HILDING (1975). For spraying, AdRIANSEN (1983) recommends ancymidol concentrations of 5 $-150 \mathrm{ppm}$, depending on the species.

The increase in width was effectively reduced by ancymidol but not by chlormequat.
It has been shown that the width of Elatior begonias is significantly reduced only when there is excessive reduction of height (KrausKOPF and Nelson 1976, Will 1977, SCHENK and BRUNDERT 1980).

The effect of ancymidol on the flower stalks was the same as on the growth in general: excessive reduction, which made the plants treated with ancymidol unsaleable. Chlormequat was effective in reducing the length of the flower stalks when used two or three times at any concentration. The effectiveness of chlormequat in reducing the length of the flower stalks was also noted by SANDVED (1972) and Hilding (1975).

Plants of the best quality, and thus the greatest proportions of saleable plants, were obtained by spraying once with 500 or 1000 ppm chlormequat or not using growth retardants at all. With the cultivar 'Schwabenland', HildiNG (1975) obtained plants of the best quality by spraying once with $0.1 \%$ (1000 ppm) chlormequat.

The reduction in quality and in the proportion of saleable plants was mainly due to long

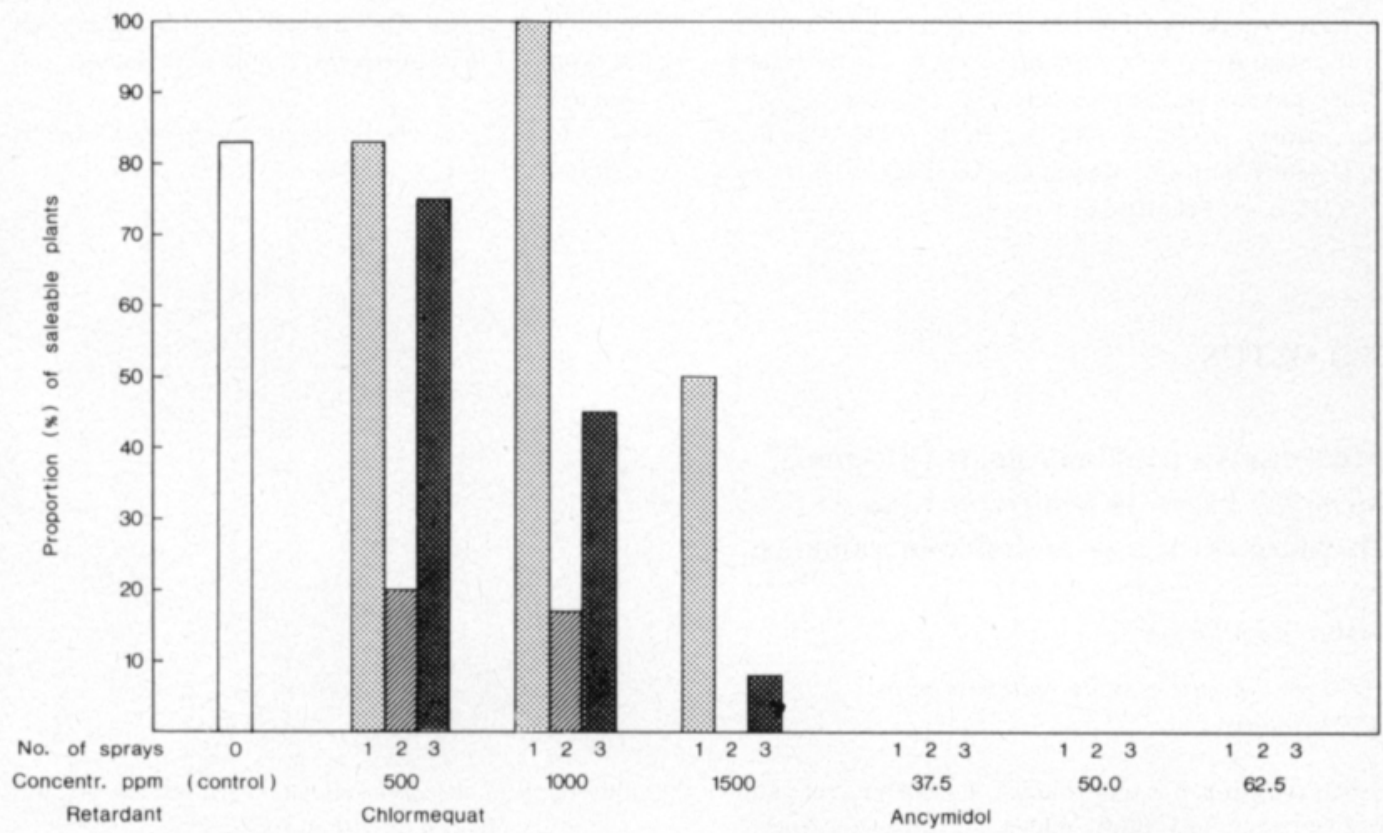

Fig. 2. The effect of chlormequat and ancymidol sprays on the proportion (\%) of saleable plants in Elatior begonia 'Afrodite Limelight'. 
flower and leaf stalks and elongated growth (untreated plants) or to short flower and leaf stalks and excessively compact growth (treated plants). There was also the problem of oblique growth, a growth habit which leads to the plant bending to one side and having a front and a back. The bending was independent of the direction of incoming daylight. Oblique growth was noted in all groups, even in plants dwarfed by ancymidol and thus not having a heavy crown. In groups with little or no growth retardation, the oblique growth habit could be overcome by supporting the crown at an early stage with two or three sticks. The oblique growth habit has been observed among other micropropagated Elatior begonia cultivars as well (RoIVAINEN 1987). The reason for such growth is unknown.

This experiment with the cultivar 'Afrodite Limeligth' did not reveal luxuriant growth or overall delays in flowering, growth habits which have been associated with micropropagated Elatior begonias. One treatment with chlormequat at low concentrations (500 or $1000 \mathrm{ppm}$ ) proved to be useful in reducing the length of the flower stalks and making the plants more compact.

Acknowledgements. The author would like to thank the horticultural foundation of Nikolai and Ljudmila Borisoff for financial support, and OY Hortus AB for cooperation.

\section{References}

Adriansen, E. 1983. Kemisk vaekstregulering. Potteplanter I. Produktion, metoder, midler, p. 150-171. Ed. Christensen, O. V., Klougart, A., Pedersen, I. S. \& Wikesjō, K. Kobenhavn.

Hentig, W.-U. von \& KnÖsel, K. 1984. So behalten Kleinpflanzen im Sommer ihren Charakter. Gb + Gw 84: 1023-1026.

HiLDING, A. 1975. Inverkan av temperatur, toppning och retarderande medel pá tillväxt och utveckling av höstbegonia, Begonia $\times$ hiemalis. Sveriges Lantbrukshögskolans medd., Serie A, nr. 252. Uppsala.

Krauskopf, D. M. \& Nelson, P. V. 1976. Chemical Height Control of Rieger Elatior Begonia. J. Amer. Soc. Hort. Sci. 101: 618-619.

\section{SELOSTUS}

\section{Mikrolisätyn pauliinabegonian (Begonia $\times$ hiemalis) kasvu ja kehitys in vivo.}

\section{Klormekvatin ja ansimidolin vaikutus.}

\author{
Päivi Roivainen \\ Helsingin yliopisto, puutarhatieteen laitos, \\ 00710 Helsinki
}

Mikrolisäyksen avulla voidaan tuottaa terveită pauliinabegonian taimia, mutta niiden jatkokasvatus on osoit-

Ms received October 5, 1987
SANDVEd, G. 1972. Effekt av CCC til hiemalisbegonia. Gartner Yrket 62: 508.

- 1984. Veksthemmende midler til utplantingsplanter. Gartner Yrket 74: 48-50.

SCHENK, M. \& BRUndert, W. 1980. Elatior-begonien. CCC-Behandlung in den lichtarmen Monaten. Gb + Gw BO: 1061-1062.

WıKESJö, K. 1978. Växtreglerande medel till krukvăxter, snittblommor och utplanteringsväxter. Sveriges Lantbruksuniv., Konsulentavd. rapp., Trädgård 130. Alnarp.

WILL, H. 1977. Wachstumsregulatoren bei Elatiorbegonien. Gb + Gw 77: 840-841.

tautunut ongelmalliseksi. Taimien kasvu on rehevăä, juurenniska jảä ohueksi ja kukinta viivästyy.

Kasvua hidastavien kasvunsääteiden vaikutuksen tutkimiseksi jărjestettiin kevăăllä 1987 pauliinabegonialajik- 
keella 'Afrodite Limelight' koe, jossa oli mukana kaksi kasvunhidastajaa, klormekvatti ja ansimidoli. Kumpaakin ainetta ruiskutettiin kolmena konsentraationa: 500, 1000 tai 1500 ppm klormekvattia tai 37.5, 50.0 tai 62.5 ppm ansimidolia. Käsittelykertoja oli 1,2 tai 3. Lisäksi kokeessa oli mukana kăsittelemătön kontrolliryhmä.

Kasvunhidastajilla kăsitellyt taimet eivăt muuten poikenneet merkitsevăsti kukinnan alkamisen ja myyntikelpoisuuden ajankohdan suhteen kăsittelemăttömistä taimista, paitsi 2 kertaa 1000 ppm:n klormekvattiliuoksella ruiskutetut taimet aloittivat kukinnan viikkoa myöhemmin kuin käsittelemăttömăt taimet. Molemmat kasvunsäăteet hillitsivăt tehokkaasti taimien pituuskasvua, an- simidoli myös leveyskasvua. Kukkavanat olivat merkitsevăsti lyhyempiä ansimidolilla tai 2 tai 3 kertaa klormekvatilla kåsitellyissă taimissa kontrolliryhmään verrattuna. Haarojen, kukkien ja nuppujen lukumäärään sekä juurenniskan läpimittaan ei kasvunsäädekãsittelyillă ollut vaikutusta.

Eniten myyntikelpoisia kasveja saatiin ruiskuttamalla kerran 500 tai 1000 ppm:n klormekvattiliuoksella sekä ilman kasvunsäädekăsittelyă. Kokeessa käytetyt ansimidolikonsentraatiot olivat liian korkeita, sillä kaikki ansimidolilla käsitellyt taimet jäivăt hyvin pieniksi ja olivat myyntikelvottomia. 